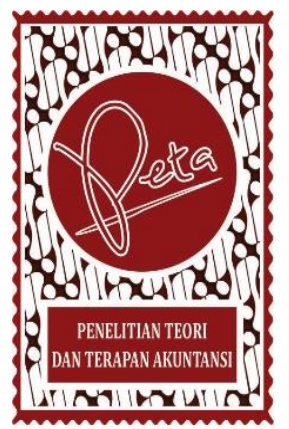

\title{
KINERJA KEUANGAN DAN NON KEUANGAN
} PERHOTELAN

\section{${ }^{1}$ Hernawati Pramesti}

${ }^{2}$ Yochevyn Agvyanda Sanjaya

${ }^{3}$ Basuki Nugraha

${ }^{1,2,3}$ Universitas Kristen Surakarta, Jalan Monginsidi No.36-38, Gilingan, Kota Surakarta, Jawa Tengah

surel : hernawatipram@gmail.com

Abstrak. Kinerja Keuangan Dan Non Keuangan Perhotelan. Penelitian dilakukan guna menganalisis faktor sistem pengendalian manajemen padakinerja keuangan dan nonkeuangan pada perhotelan. Penggunaan metode purposive sampling digunakan untuk mengambil sampel. Analisis data untuk menguji hipotesis menggunakan analisis regresi dan uji t. Hasil dari analisis data dan pembahasan dapat dikemukakan kesimpulan bahwa hipotesis pertama terbukti, hal ini berarti penerapan sistem pengendalian manajemen akan menyebabkan meningkatnya pendapatan Hotel. Hipotesis kedua terbukti, hal ini berarti penerapan sistem pengendalian manajemen akan menyebabkan meningkatnya kepuasan Customer dan kualitas pelayanan pada Hotel. Bagi peneliti selanjutnya dapat melakukan pengujian kembali dengan menambahkan variabel independen lainnya seperti sistem pengukuran kinerja, dan sistem penghargaan untuk memperbaiki model regresi dan dapat digunakan untuk memperkaya penelitian. Serta Penelitian yang akan datang sebaiknya bisa digeneralisasi dengan obyek penelitian perusahaan jasa yang lain contohnya rumah sakit, PDAM, Telkom, dan lain sebagainya.

Kata kunci : Sistem pengendalian manajemen, kinerja keuangan dan kinerja nonkeuangan

Abstract. Hospitality Financial and Non-Financial Performance. The research was conducted to analyze the factors of the management control system on financial and nonfinancial performance in hospitality. The use of purposive sampling method is used to take samples. Data analysis to test the hypothesis using regression analysis and t test. The results of the data analysis and discussion can be concluded that the first hypothesis is proven, this means that the implementation of a management control system will lead to an increase in hotel revenues. The second hypothesis is proven, this means that the implementation of a management control system will lead to increased customer satisfaction and service quality at the hotel. For further researchers, it can be re-tested by adding other independent variables such as a performance measurement system, and a reward system to improve the regression model and can be used to enrich research. And future research should be generalized to other service companies' research objects, for example hospitals, PDAM, Telkom, and so on.

Keywords: Management control system, financial performance and non-financial performance 


\section{PENDAHULUAN}

di Surakarta $\begin{gathered}\text { Perkembangan pariwisata } \\ \text { mengalami }\end{gathered}$ peningkatan yang besar baik domestik ataupun mancanegara. Dinas pariwisata Surakarta mencatat kenaikan angka pada tahun 2017 yaitu 4.395 .550 ke tahun 2018 yaitu 4.459 .884 (www.surakarta.go.id).

Peningkatan disebabkan adanya even-even bertaraf nasional dan internasional. Event-event yang sering diadakan di Surakarta menjadi peluang besar bagi usahausaha di bidang pariwisata seperti hotel, restoran, tempat wisata dan lain sebagainya. Peluang tersebut diambil oleh usaha yang bergerak di bidang perhotelan sehingga peneliti memfokuskan penelitian perhotelan.

Pembangunan hotel sebagai tempat penginapan yang nyaman merupakan salah satu faktor penting bagi wisatawan atau customer yang ingin menggunakan jasa perhotelan. Dengan banyaknya perkembangan pembangunan hotel mengakibatkan persaingan hotel sangat ketat, oleh karena itu hotel membutuhkan seorang manajer yang mampu dan dapat bekerja secara profesional dalam meningkatkan nilai kualitas pelayanan. Nilai kualitas pelayanan akan menentukan kepuasan konsumen terhadap jasa yang diberikan dan akan tercipta loyalty konsumen, sehingga hotel akan memiliki kemampuan untuk bersaing (Eka 2009, Chandra 2019). Untuk meningkatkan kualitas pelayanan dibutuhkan suatu sistem pengendalian manajemen yang baik. Sistem pengendalian manajamen adalah suatu sistem yang melakukan pengawasan terhadap segala kegiatan operasional perusahaan mulai dari perencanaan, pengorganisasian, pengkoordinasian dan evaluasi atas hasil kerja yang telah dicapai.

Berdasarkan hal-hal di atas, tujuan dilakukannya penelitian ini adalah untuk melakukan analisis mengenai pengaruh sistem pengendalian manajemen terhadap kinerja keuangan dan nonkeuangan pada Hotel di kota Surakarta.

\section{TELAAH LITERATUR}

\section{Pengertian Sistem Pengendalian Manajemen}

Sistem pengendalian manajemen enurut Anthony dan Govindarajan (2011) merupakan keharusan dalam suatu organisasi yang mempraktikkan desentralisasi dan menurut Helmy (2015) sistem pengendalian manajemen yaitu suatu prosedur baik secara formal maupun secara informal yang diciptakan untuk membuat situasi yang dapat meningkatkan peluang dan pencapaian harapan disertai dengan perolehan hasil (output) yang menjad target, dimana tetap fokus kepada tujuan atau target serta perilaku yang akan diinginkan oleh organisasi.

Sistem pengendalian manajemen adalah sistem yang digunakan oleh manajemen untuk mempengaruhi para anggota organisasinya agar mengimplemenatsikan strategistrategi organisasi secara efisein dan efektif dalam rangka mencapai tujuan organisasi (Sumarsan, 2013). Sistem yang digunakan oleh 
manajemen untuk mengendalikan aktivitas suatu organisasi disebut sistem pengendalian manajemen (Asri 2013). Jadi sistem pengendalian manajemen merupakan suatu sistem yang digunakan oleh manajemen untuk mempengaruhi para anggota organisasinya supaya dapat mengimplementasikan strategistrategi organisasi secara efisien dan efektif guna pencapaian tujuan organisasi.

$$
\text { Menurut Rinny }
$$

Sistem pengendalian manajemen meliputi baik tindakan untuk menuntun dan memotivasi usaha pencapaian tujuan maupun digabungkan untuk saling dibandingkan setiap saat. Data aktual disusun sesuai dengan data yang direncanakan dan diukur secara konsisten untuk memungkinkan perbandingan antara hasil aktual dengan hasil yang diinginkan.

\section{Kinerja Keuangan}

Kinerja keuangan menurut Melina (2014) adalah kemampuan suatu perusahaan dalam memberikan laba yang tetap berfokus pada hasil-hasil moneter seperti laba bersih, pengembalian atas modal, perputaran kas, dan sebagainya sedangkan kinerja keuangan menurut Fahmi (2013) yaitu analisis yang dilakukan untuk mengetahui sudah sejauh mana suatu perusahaan telah melakukan aturan-aturan pelaksanaan keuangan secara baik dan benar. Untuk menilai kinerja suatu perhotelan dapat menggunakan current ratio untuk ratio likuiditas, time interest earned ratio untuk ratio solvabilitas, return on total asset ratio untuk ratio profitabilitas, dan return on equity serta ratio-rutio lainnya yang disesuaikan dengan keadaan dan kebutuhan perusahaan.

\section{Kinerja Nonkeuangan}

Kinerja nonkeuangan merupakan kinerja perusahaan yang digunakan untuk memastikan dari sudut pandang nonkeuangan apakah sudah tercapai baik secara efektif dan efisien atau belum (Melina 2014). Penilaian kinerja nonkeuangan diantara dengan mengetahui seberapa besar kepuasan pelanggan, seberapa baik mutu produk, seberapa sesuai ketepatan waktu, dan besarnya semangat kerja dari karyawan. Bentuk pengukuran kinerja nonkeuangan dapat dilihat pada balance scorecard yang menilai kinerja perusahaan berdasarkan empat dimensi yaitu finansial, pelanggan, proses bisnis internal, dan pembelajaran dan pertumbuhan. Dua indikator dari kinerja nonkeuangan yang digunakan dalam penelitian ini adalah kepuasan pelanggan dan kepuasan karyawan. Kepuasan pelanggan merupakan suatu penilaian terhadap tingkat kepuasan pelanggan pada perusahaan dan kepuasan karyawan adalah seberapa besar tingkat kepuasan karyawan yang bekerja bagi perusahaan.

\section{HIPOTESIS}

Hasil penelitian dari Melina (2014) menyatakan bahwa terdapat pengaruh yang positif signifikan sistem pengendalian manajemen terhadap kinerja keuangan. Hal ini 
menunjukkan untuk memperoleh kinerja keuangan yang lebih tinggi dapat dipengaruhi oleh sistem pengendalian manajemen. Hasil penelitian ini didukung oleh penelitian yang dilakukan oleh Eka (2009) dan Chandra (2019) yang menyatakan Sistem Pengendalian Manajemen berpengaruh positif terhadap kinerja keuangan.

H1 : Penggunaan sistem pengendalian manajemen berpengaruh terhadap kinerja keuangan pada Hotel.

Menurut Melina (2014) sistem pengendalian manajemen berpengaruh signifikan dan positif terhadap kinerja nonkeuangan. Hal ini berarti untuk perusahaan dapat memperoleh kinerja nonkeuangan yang lebih tinggi dipengaruhi oleh sistem pengendalian manajemen.
H2 : Penggunaan sistem pengendalian manajemen berpengaruh terhadap kinerja nonkeuangan pada Hotel.

\section{METODE PENELITIAN}

1. Populasi dan Sampel

Populasi dalam penelitian ini adalah : Manajer, Staff Keuangan, Staff bagian pemasukan, Staff bagian pengeluaran, Staff bagian pembukuan, Staff Perpajakan, sedangkan teknik pengambilan sampel yang digunakan metode purposive sampling.

2. Pengukuran Variabel dalam Penelitian

Variabel independen dalam penelitian ini adalah sistem pengendalian manajemen yang diukur menggunakan skala likert. Variabel dependen penelitian ini adalah Kinerja Keuangan dan Kinerja Nonkeuangan.

\section{a. Kinerja Keuangan}

Menilai kinerja suatu hotel menggunakan current ratio untuk ratio likuiditas, time interest earned ratio untuk ratio solvabilitas, dan return on total asset ratio dan return on equity untuk ratio profitabilitas (Yochevyn, 2019).

1) Current Ratio menurut Wiratna (2017) merupakan salah satu rasio yang paling umum digunakan untuk mengukur likuiditas hotel. Current Ratio ini

\section{Current Ratio $=$}

dihitung dengan formula :
Current Assets

Current Liabilities

2) Rasio yang digunakan untuk mengukur rasio solvabilitas adalah Time Interest Earned (TIR). Menurut Wiratna (2017) merupakan besarnya jaminan keuntungan untuk membayar bunga utang jangka panjang. Selain itu, terdapat suatu ukuran yang sering digunakan para kreditor guna mengukur keamanan investasi mereka pada sualu hotel. Yaitu suatu ratio yang dihitung dengan formula : 
3) Ratio profitabilitas dalam penelitian ini diukur dengan skala rasio Return On Total Asset

a. Return On Total Asset (ROA).

Menurut Kasmir (2016) ROA adalah ratio yang digunakan untuk mengukur kemampuan dari modal yang diinvestasikan dalam keseluruhan aktiva untuk menghasilkan keuntungan netto. Ratio ini dihitung dengan formula :

$$
\begin{aligned}
\text { Times Interest Earned } & =\frac{\text { Earning Before Interest Taxes }}{\text { Interest Expense }} \\
\text { Return On Total Asset } & =\frac{\text { Earning After Interest \& Taxes }}{\text { Asset Tvetuo }}
\end{aligned}
$$

\section{b. Return On Equity (ROE)}

Return on equity (ROE) merupakan pengukuran untuk menilai besaran tingkat pengembalian modal. Rumus menghitung ROE menurut Irham (2012) adalah sebagai berikut :

$$
\text { Return On Equity }=\frac{\text { Net income (annual) }}{\text { Snarenotaers Equity }}
$$

\section{b. Kinerja Nonkeuangan}

Dua indikator yang digunakan untuk mengukur kinerja nonkeuangan adalah kepuasan pelanggan dan kepuasan pekerja. Kepuasan pelanggan diukur berdasarkan tingkat kepuasan dari pelanggan terhadap perusahaan yang bersangkutan. Kepuasaan pekerja diukur berdasarkan tingkat kepuasan dari karyawan yang bekerja untuk perusahaan tersebut. Responden diminta untuk mengindikasikan kinerja nonkeuangan dari perusahaanperusahaan yang bersangkutan dengan memberikan respon ke dalam lima poin skala likert.

\section{Teknik Analisis Data}

\section{a. Uji Kualitas Data} 1). Uji Validitas Sebuah instrumen dikatakan valid apabila nilai $r$ hitung $>$ dari $\mathrm{r}$ tabel, sedangkan dinyatakan tidak valid bila $r$ hitung < dari $\mathrm{r}$ tabel, dengan tingkat kepercayaan 0,05.

\section{2). Uji Reliabilitas}

Uji reliabilitas dapat dilakukan secara bersama sama terhadap seluruh butir pertanyan. Jika Alpha $>0,60$ maka dapat dikatakan reliabel.

\section{b. Analisis Regresi Linier}

Model regresi linear ditunjukkan oleh persamaan berikut: 


$$
\begin{aligned}
& Y 1=a+b 1 X 1+e \\
& Y 2=a+b 2 X 1+e
\end{aligned}
$$

Keterangan:

Y1 = Kinerja Keuangan

$\mathrm{Y} 2$ = Kinerja Nonkeuangan

a $=$ Konstanta

b1,2 $=$ Koefisien arah regresi dari variabel independen

$\mathrm{X} 1$ = Sistem Pengendalian Manajemen

$\mathrm{e}=$ Error item

\section{c. Uji Signifikan Parsial (Uji Statistik T)}

Pengujian ini dilakukan dengan membandingkan nilai $t_{\text {hitung }}$ dengan nilai $t_{\text {tabel }}$ dengan menggunakan taraf signifikansi $5 \%$.

\section{d. Uji Koefisien Determinasi}

Nilai koefisien deteminasi terletak antara 0 dan $1\left(0<\mathrm{R}^{2}<1\right)$ dimana semakin tinggi nilai $\mathrm{R}^{2}$ suatu regresi atau semakin mendekati 1 , maka hasil regresi tersebut baik. Nilai yang mendekati 1 berarti bahwa variabel-variabel independen mampu memberikan hampir semua informasi yang dibutuhkan untuk memprediksi variasi variabel dependen.

\section{HASIL DAN PEMBAHASAN}

\section{ANALISIS DATA}

a. Uji Kualitas data

1). Uji Validitas

Sebuah instrumen dikatakan valid apabila nilai $\mathrm{r}$ hitung $>$ dari $\mathrm{r}$ tabel, sedangkan dinyatakan tidak valid bila $\mathrm{r}$ hitung $<$ dari $\mathrm{r}$ tabel, dengan tingkat kepercayaan 0,05 .

\section{Tabel 1}

Hasil Uji Validitas Sistem Pengendalian Manjemen

\begin{tabular}{|c|c|c|c|c|c|c|c|}
\hline X & $\begin{array}{c}\text { rhitu } \\
\text { ng }\end{array}$ & $\begin{array}{c}\text { rtab } \\
\text { el }\end{array}$ & $\begin{array}{c}\text { Kesimpul } \\
\text { an }\end{array}$ & $\begin{array}{c}\text { X } \\
\text { ng }\end{array}$ & $\begin{array}{c}\text { rtab } \\
\text { el }\end{array}$ & $\begin{array}{c}\text { Kesimpul } \\
\text { an }\end{array}$ \\
\hline $\mathrm{X} 1.1$ & 0,518 & $\begin{array}{c}0,33 \\
8\end{array}$ & Valid & $\begin{array}{c}\mathrm{X} 1.1 \\
8\end{array}$ & 0,505 & $\begin{array}{c}0,33 \\
8\end{array}$ & Valid \\
\hline $\mathrm{X} 1.2$ & 0,489 & $\begin{array}{c}0,33 \\
8\end{array}$ & Valid & $\begin{array}{c}\mathrm{X} 1.1 \\
9\end{array}$ & 0,627 & 0,33 & Valid \\
& & 8 & & 9 & & 8 \\
\hline $\mathrm{X} 1.3$ & 0,464 & $\begin{array}{c}0,33 \\
8\end{array}$ & Valid & $\mathrm{X} 1.2$ & 0,419 & 0,33 & Valid \\
& & 8 & 0 & 8 & \\
\hline $\mathrm{X} 1.4$ & 0,416 & 0,33 & Valid & $\mathrm{X} 1.2$ & 0,518 & 0,33 & Valid \\
& & 8 & & 1 & & 8 & \\
\hline $\mathrm{X} 1.5$ & 0,489 & 0,33 & Valid & $\mathrm{X} 1.2$ & 0,497 & 0,33 & Valid \\
& & 8 & & 2 & & 8 & \\
\hline
\end{tabular}




\begin{tabular}{|c|c|c|c|c|c|c|c|}
\hline X1.6 & 0,606 & $\begin{array}{c}0,33 \\
8\end{array}$ & Valid & $\begin{array}{c}\mathrm{X} 1.2 \\
3\end{array}$ & 0,505 & $\begin{array}{c}0,33 \\
8\end{array}$ & Valid \\
\hline X1.7 & 0,523 & $\begin{array}{c}0,33 \\
8\end{array}$ & Valid & $\begin{array}{c}\mathrm{X} 1.2 \\
4\end{array}$ & 0,505 & $\begin{array}{c}0,33 \\
8\end{array}$ & Valid \\
\hline X1.8 & 0,605 & $\begin{array}{c}0,33 \\
8\end{array}$ & Valid & $\begin{array}{c}\mathrm{X} 1.2 \\
5\end{array}$ & 0,414 & $\begin{array}{c}0,33 \\
8\end{array}$ & Valid \\
\hline X1.9 & 0,379 & $\begin{array}{c}0,33 \\
8\end{array}$ & Valid & $\begin{array}{c}\mathrm{X} 1.2 \\
6\end{array}$ & 0,708 & $\begin{array}{c}0,33 \\
8\end{array}$ & Valid \\
\hline $\begin{array}{c}\mathrm{X} 1.1 \\
0\end{array}$ & 0,419 & $\begin{array}{c}0,33 \\
8\end{array}$ & Valid & $\begin{array}{c}\mathrm{X} 1.2 \\
7\end{array}$ & 0,464 & $\begin{array}{c}0,33 \\
8\end{array}$ & Valid \\
\hline $\begin{array}{c}\mathrm{X} 1.1 \\
1\end{array}$ & 0,605 & $\begin{array}{c}0,33 \\
8\end{array}$ & Valid & $\begin{array}{c}\mathrm{X} 1.2 \\
8\end{array}$ & 0,543 & $\begin{array}{c}0,33 \\
8\end{array}$ & Valid \\
\hline $\begin{array}{c}\mathrm{X} 1.1 \\
2 \\
\end{array}$ & 0,489 & $\begin{array}{c}0,33 \\
8 \\
\end{array}$ & Valid & $\begin{array}{c}\mathrm{X} 1.2 \\
9 \\
\end{array}$ & 0,578 & $\begin{array}{c}0,33 \\
8 \\
\end{array}$ & Valid \\
\hline $\begin{array}{c}\mathrm{X} 1.1 \\
3\end{array}$ & 0,523 & $\begin{array}{c}0,33 \\
8\end{array}$ & Valid & $\begin{array}{c}\mathrm{X} 1.3 \\
0\end{array}$ & 0,522 & $\begin{array}{c}0,33 \\
8\end{array}$ & Valid \\
\hline $\begin{array}{c}\mathrm{X} 1.1 \\
4\end{array}$ & 0,518 & $\begin{array}{c}0,33 \\
8\end{array}$ & Valid & $\begin{array}{c}\mathrm{X} 1.3 \\
1\end{array}$ & 0,708 & $\begin{array}{c}0,33 \\
8\end{array}$ & Valid \\
\hline $\begin{array}{c}\mathrm{X} 1.1 \\
5\end{array}$ & 0,518 & $\begin{array}{c}0,33 \\
8 \\
\end{array}$ & Valid & $\begin{array}{c}\mathrm{X} 1.3 \\
2 \\
\end{array}$ & 0,578 & $\begin{array}{c}0,33 \\
8\end{array}$ & Valid \\
\hline $\begin{array}{c}\mathrm{X} 1.1 \\
6\end{array}$ & 0,578 & $\begin{array}{c}0,33 \\
8\end{array}$ & Valid & $\begin{array}{c}\mathrm{X} 1.3 \\
3\end{array}$ & 0,572 & $\begin{array}{c}0,33 \\
8\end{array}$ & Valid \\
\hline $\begin{array}{c}\mathrm{X} 1.1 \\
7\end{array}$ & 0,464 & $\begin{array}{c}0,33 \\
8\end{array}$ & Valid & & & & \\
\hline
\end{tabular}

Sumber : Data diolah peneliti (2019)

Tabel 2

Hasil Uji Validitas Kinerja Keuangan

\begin{tabular}{|c|c|c|c|}
\hline Y1 & rhitung & Rtabel & kesimpulan \\
\hline Y1.1 & 0,453 & 0,338 & Valid \\
\hline Y1.2 & 0,393 & 0,338 & Valid \\
\hline Y1.3 & 0,368 & 0,338 & Valid \\
\hline Y1.4 & 0,386 & 0,338 & Valid \\
\hline
\end{tabular}

Sumber : Data diolah peneliti (2019)

Tabel 3

Hasil Uji Validitas Kinerja Nonkeuangan

\begin{tabular}{|c|c|c|c|}
\hline Y2 & rhitung & Rtabel & kesimpulan \\
\hline Y2.1 & 0,446 & 0,338 & Valid \\
\hline Y2.2 & 0,446 & 0,338 & Valid \\
\hline
\end{tabular}


Sumber : Data diolah peneliti (2019)

b.Uji Reliabilitas

\section{Tabel 4 \\ Hasil Uji Reliabilitas SPM}

\begin{tabular}{l|l|lr}
$\begin{array}{l}\text { Cronbach's } \\
\text { Alpha }\end{array}$ & $\begin{array}{c}\text { Cronbach's Alpha Based on } \\
\text { Standardized Items }\end{array}$ & N of Items & \\
\hline, 930 & \multicolumn{1}{c}{, 933} & 33 \\
\hline Sumber : Data diolah peneliti (2019)
\end{tabular}

Menurut hasil uji reliabel di atas nilai Cronbach' s Alpha 0, 930 $>$ 0,600, maka data Sistem Pengendalian Manajemen dinyatakan reliabel.

\section{Tabel 5}

\section{Hasil Uji Reliabilitas Kinerja Keuangan}

\begin{tabular}{l|l|ll}
$\begin{array}{l}\text { Cronbach's } \\
\text { Alpha }\end{array}$ & $\begin{array}{c}\text { Cronbach's Alpha Based on } \\
\text { Standardized Items }\end{array}$ & N of Items & \\
\hline, 619 &, 619 & 4 \\
\hline Sumber : Data diolah peneliti (2019)
\end{tabular}

Berdasarkan hasil uji reliabel di atas nilai Cronbach' s Alpha 0,619 > 0,600, maka data Kinerja Keuangan dinyatakan reliabel.

\section{Tabel 6}

\section{Hasil Uji Reliabilitas Kinerja Nonkeuangan}

\begin{tabular}{l|l} 
Cronbach's & Cronbach's Alpha Based or
\end{tabular}

Alpha Standardized Items $\mathrm{N}$ of Items

\begin{tabular}{rrr}
, 611 &, 617 & 2 \\
\hline
\end{tabular}

Sumber : Data diolah peneliti (2019)

Berdasarkan hasil uji reliabel di atas nilai Cronbach's Alpha $0,611>0,600$, maka data Kinerja Nonkeuangan dinyatakan reliabel.

c. Analisis Regresi Sederhana

Berdasarkan hasil peenelitian, maka persamaan regresi dirumuskan sebagai berikut:

$$
\begin{aligned}
& \mathrm{Y} 1=-0,148+0,122 \mathrm{X} 1+\varepsilon \\
& \mathrm{Y} 2=0,310+0,061 \mathrm{X} 1+\varepsilon
\end{aligned}
$$


d. Uji Signifikan Parsial (Uji Statistik t)

\section{Tabel 7}

\section{Hasil Uji t Kinerja Keuangan}

\begin{tabular}{c|c|c|c|c}
\multicolumn{1}{c|}{ Variable } & $\mathrm{t}_{\text {hitung }}$ & $\mathrm{t}_{\text {tabel }}$ & Sig & interpretasi \\
\hline $\begin{array}{l}\text { Sistem Pengendalian } \\
\text { Manajemen }\end{array}$ & 5,409 & 2,037 & 0,000 & H1 diterima \\
\hline
\end{tabular}

Sumber : Data diolah

Berdasarkan hasil pada tabel dapat disimpulkan bahwa H0 ditolak dan H1 diterima.

\section{Tabel 8}

Hasil Uji t Kinerja Nonkeuangan

\begin{tabular}{c|c|c|c|c}
\multicolumn{1}{c|}{ Variable } & $\mathrm{t}_{\text {hitung }}$ & $\mathrm{t}_{\text {tabel }}$ & Sig & Interpretasi \\
\hline $\begin{array}{l}\text { Sistem Pengendalian } \\
\text { Manajemen }\end{array}$ & 3,767 & 2,037 & 0,001 & H2 diterima \\
\hline
\end{tabular}

Berdasarkan hasil pada tabel 2 dapat disimpulkan bahwa $\mathrm{H} 0$ ditolak dan H1 diterima.

2. Koefisien Determinasi

Tabel 9

Hasil Koefisien Determinasi Kinerja Keuangan

\begin{tabular}{cc}
\hline Model & R. Square \\
\hline 1 & 0,478 \\
\hline Sumber : Data diolah peneliti $(2019)$
\end{tabular}

Berdasarkan tabel di atas diperoleh nilai sebesar 0,478. Hal ini menunjukkan bahwa hanya $47,8 \%$ variasi dari sistem pengendalian manajemen.

Tabel 10

Hasil Koefisien Determinasi Kinerja Nonkeuangan

\begin{tabular}{cc}
\hline Model & R. Square \\
\hline 1 & 0,307 \\
\hline Sumber : Data diolah peneliti $(2019)$
\end{tabular}

Berdasarkan tabel 4diperoleh nilai sebesar 0,307. Hal ini menunjukkan bahwa hanya $30,7 \%$ variasi dari sistem pengendalian manajemen. 


\section{PEMBAHASAN}

Berdasarkan hasil dari uji $\mathrm{t}$ diperoleh hasil sistem pengendalian manajemen terhadap kinerja keuangan diperoleh $t_{\text {hitung }}$ sebesar 5,409 dan signifikansi sebesar 0,000 . nilai $t_{\text {hitung }}$ lebih besar dari $t_{\text {tabel }}$ dan signifikansi sistem pengendalian manajemen terhadap kinerja keuangan lebih kecil dari 0,05 dan nilai koefisien regresi 0,122 . Hal ini berarti semakin tinggi sistem pengendalian manajemen, maka akan semakin meningkatkan kinerja keuangan pada Hotel. Hasil uji $t$ sistem pengendalian manajemen terhadap kinerja nonkeuangan diperoleh $t_{\text {hitung }}$ sebesar 3,767 dan signifikansi sebesar 0,001 . Nilai $t_{\text {hitung }}$ lebih besar dari $t_{\text {tabel }}$ dan signifikansi sistem pengendalian manajemen terhadap kinerja nonkeuangan lebih kecil dari 0,05 dan nilai koefisien regresi 0,122 . Hal ini berarti semakin tinggi sistem pengendalian manajemen, maka akan meningkatkan kinerja nonkeuangan pada Hotel.

\section{KESIMPULAN}

a. H1 yang menyatakan sistem pengendalian manajemen berpengaruh signifikan dan positif terhadap kinerja keuangan terbukti. Maka diartikan bahwa semakin tinggi sistem pengendalian manajemen, maka akan semakin meningkatkan kinerja keuangan pada Hotel. Penerapan sistem pengendalian manajemen akan menyebabkan meningkatnya pendapatan Hotel. Hasil penelitian ini selaras dengan penelitian yang dilakukan Eka (2009) dan Melina (2014).

b. $\mathrm{H} 2$ yang menyatakan sistem pengendalian manajemen berpengaruh signifikan dan positif terhadap kinerja keuangan terbukti. Hal tersebut dapat diartikan bahwa semakin tinggi sistem pengendalian manajemen, maka akan semakin meningkatkan kinerja nonkeuangan pada Hotel. Penerapan sistem pengendalian manajemen akan menyebabkan meningkatnya kepuasan Customer dan kualitas pelayanan pada Hotel. Hasil penelitian ini selaras dengan penelitian yang dilakukan Melina (2014).

\section{Keterbatasan}

Keterbatasan dalam penelitian ini yaitu variabel independen yang digunakan dalam penelitian ini hanya mampu menjelaskan pengaruh sebesar $47,8 \%$ terhadap variabel dependen kinerja keuangan. Sedangkan untuk menjelaskan pengaruh SPM terhadap kinerja nonkeuangan hanya sebesar $30,7 \%$, sisanya $69,3 \%$ dipengaruhi oleh variabel lain.

\section{Saran}

a. Bagi peneliti selanjutnya dapat melakukan pengujian kembali dengan menambahkan variabel independen lainnya seperti sistem pengukuran kinerja, dan sistem penghargaan untuk memperbaiki model regresi dan dapat digunakan untuk memperkaya penelitian. 
b. Penelitian yang akan datang sebaiknya bisa digeneralisasi dengan obyek penelitian perusahaan jasa yang lain contohnya rumah sakit, PDAM, Telkom, dan lain sebagainya.

\section{DAFTAR RUJUKAN}

Anonimus, 2019, Kunjungan Wisatawan ke Solo Terus Meningkat,http://surakarta.g o.id/?p=8876, diambil pada tanggal 1 November 2019

Asri Purnama dan Syaefullah., 2013., Pengaruh Struktur Dan Proses Sistem Pengendalian Manajemen Terhadap Kinerja Instalasi Rawat Inap Pada Rumah Sakit Umum Provinsi (Rsup) Nusa Tenggara Barat.

Chandra Eddy Thungasal dan Hotlan Siagian., 2019., Pengaruh Kualitas Layanan dan Harga Terhadap Loyalitas Pelanggan Melalui Kepuasan Pelanggan Pada Hotel Kasuari

Eka Nurmala Sari.,2009., Pengaruh Sistem Pengendalian Manajemen Terhadap Kinerja Keuangan Peusahaan Pada Hotel Berbintang Di Kota Medan.

Fahmi,Irham.,2012.,Manajemen Investasi.,Salemba Empat., Jakarta

Fahmi, Irham., 2013., Analisis Laporan Keuangan., Alfabeta., Bandung
Helmy Febry Yudhistira, 2015., Pengaruh Sistem Pengendalian Manajemen, Sistem Pengukuran Kinerja, Dan Sistem Penghargaan Terhadap Kinerja Manajer Unit (Studi Pada Rumah Sakit Umum Daerah Sukoharjo)

Hesti Pratipta., 2015., Evaluasi Sistem Pengendalian Manajemen Pada Pusat Pendapatan dan Pusat Biaya Untuk Meningkatkan Kinerja Manajer Penjualan.

Imas Purnamasari., 2009., Hubungan Struktur Sistem Pengendalian Manajemen dan Proses Sistem Pengendalian Manajemen dengan Kinerja Keuangan Perusahaan pada PT. Kereta Api Indonesia (Persero) .

Yochevyn Agvyanda Sanjaya., 2019., Pengaruh Sistem Pengendalian Manajemen Terhadap Kinerja Keuangan dan Nonkeuangan Studi Kasus di Hotel Asia Group Surakarta

Kadek Budi Hendrawan, Gede Adi Yuniarta, Putu Eka Dianita, dan Marvilianti Dewi.,2017., Pengaruh Trust, Gaya Kepemimpinan, Dan Sistem Pengendalian Manajemen Terhadap Kinerja Keuangan Koperasi.

Kasmir.,2016.,Analisis Laporan Keuangan.,Raja Grafindo Persada., Jakarta 
Melina Dewi., 2014.,Pengaruh Sistem Pengendalian Manajemen Terhadap Kinerja Keuangan dan Nonkeuangan pada BUMN.

Margaretha,

Farah.,2011., Manajemen

Keuangan.,Erlangga.,Jakarta

Pepmi Ari Sayekti.,2010., Pengaruh

Sistem

Pengendalian

Manajemen

Terhadap

Kualitas Kinerja dan

Konsekensinya Terhadap

Kinerja Keuangan Pada PT.

Dipo Valasindo.

Prisuda Nur Haryono.,2016., Pengaruh Sistem

Pengendalian Manajemen Terhadap Kinerja Manajerial Pada Bank Perkreditan Rakyat Karangmalang Sragen.

Putri, 2016., Pengaruh Penerapan Sistem Pengendalian Manajemen Terhadap Kinerja Manajerial (Studi Empiris pada Perusahaan Manufaktur di Kabupaten Sukoharjo)

Riny Chandra., 2017., Penerapan Sistem Pengendalian Manajemen Terhadap Kinerja Keuangan Pada PT. Indojaya Agri Nusa.

Robert N. Anthony dan Vijaya Govindarajan., 2011 ., Sistem Pengendalian Manajemen ., Karisma Publishing Group ., Edisi 12 ., Tangerang Selatan.
Sitti Hardianti Musa, 2013., Evaluasi Sistem Pengendalian Manajemen Untuk Meningkatkan Kinerja Manajer Penjualan Pada Pt. Hasjrat Abadi Manado

Thomas Sumarsan., 2013., Sistem Pengendalian Manajemen, Konsep, Aplikasi dan Pengukuran Kinerja ., Indeks., Edisi 2., Jakarta

Widodo., 2017., Metodologi Penelitian Populer \& Praktis., Rajawali Pers., edisi 1., Jakarta.

Wiratna Sujarweni., 2014., Metodologi Penelitian., Pustaka Baru Press., Edisi 1., Yogyakarta.

Wiratna

Sujarwening.,2017.,Analisis

Laporan Keuangan teori, analisis dan hasil penelitian.,Pustaka Baru Press., Yogyakarta.

Zarman Zikri, Zulbahridar, dan H. Elfi Ilham., 2014., Analisis Kinerja Keuangan Dan Non Keuangan Pemerintah Daerah Kabupaten Kampar. 